\title{
Secondary Tumors of the Ampulla of Vater: A Tale of Two Cases
}

\author{
Jafer Ali ${ }^{1, \odot}$ Asad Khan ${ }^{1}$ Mohamed H. Ahmed ${ }^{2}$ Ravi Madhotra ${ }^{1}$ \\ 1Department of Gastroenterology, Milton Keynes University \\ Hospital NHS Foundation Trust, Milton Keynes, Buckinghamshire, \\ United Kingdom \\ 2Department of Medicine and HIV Metabolic Clinic, Milton Keynes \\ University Hospital NHS Foundation Trust, Milton Keynes,

\begin{abstract}
Address for correspondence Mohamed H. Ahmed, MBBS, PhD, SCE, Department of Medicine and HIV Metabolic Clinic, Milton Keynes University Hospital NHS Foundation Trust, Eaglestone, Milton Keynes, MK6 5LD, Buckinghamshire, United Kingdom (e-mail: Mohamed.Hassan-Ahmed@mkuh.nhs.uk).
\end{abstract} Buckinghamshire, United Kingdom

\begin{abstract}
We report two cases of women with metastatic cancers to ampulla of Vater. The first was 91 years old and presented with severe anemia, due to upper gastrointestinal bleeding. She had history of renal cell cancer treated with nephrectomy 8 years ago and diagnosis confirmed to be metastasis of renal cell cancer to ampulla of Vater. The

\section{Keywords}

- ampulla of Vater

- breast cancer

- renal cell cancer second patient was 54 years old with breast cancer, metastasis and developed obstructive jaundice; diagnosis confirmed to be breast metastasis in the ampulla of Vater. Secondary tumors of the ampulla of Vater due to breast cancer and renal cell cancer are rare findings and prognosis can be poor.
\end{abstract}

\section{Introduction}

The ampulla of Vater has unique anatomy and physiological function. For instance, its main function is regulation of bile flow into the duodenum and preventing its reflux back into the biliary and pancreatic ducts. Anatomically, it is situated in the second part of duodenum, closely related to last portion of the pancreatic duct and final portion of common bile duct. ${ }^{1,2}$ Therefore, ampulla of Vater is usually affected by cancer from pancreas, biliary system, and duodenum. Despite the fact that primary neoplasm of ampulla of Vater is rare, most common primary cancer is ampulla of Vater carcinoma (AVC), this usually occurs between the ages of 60 to 70 years. AVC is shown to be involved in $30 \%$ of pancreatico-duodenectomies and $20 \%$ of all tumors involved in obstruction of the common bile duct. ${ }^{3}$ The main types of AVC are pancreatobiliary and intestinal type. These subtypes have different pathogenic and clinical characteristics. Other rare primary cancers of ampulla of Vater include neuroendocrine, adenosquamous, and papillary types. ${ }^{4}$ The metastasis to ampulla of Vater is quite rare indeed and the clinical

published online July 29, 2021
DOI https://doi.org/

$10.1055 / \mathrm{s}-0041-1732810$ ISSN 0974-2727 presentations can also be quite variable. In 2017, Sarocchi et al showed in their literature review of 32 cases published between 1989 and 2017 that the metastasis to ampulla of Vater though quite unusual, but if they do occur, then the primary cancer is usually from malignant melanoma, renal cell carcinoma, and breast cancer. ${ }^{2}$

\section{Case Presentation}

\section{Case 1}

The first patient was a 91-year-old female and presented to the medical assessment unit with shortness of breath, tiredness, and loss of appetite. Eight years ago, she had right nephrectomy as part of treatment of renal cell cancer and was subsequently discharged from the Urology, as she was deemed to be in remission. Past medical history included hypertension, osteoarthritis, and hypothyroidism. There was no previous history of NSAIDs use or alcohol intake. She was found to have severe anemia with hemoglobin levels of $71 \mathrm{~g} / \mathrm{dL}$ (normal reference range 120-130) (-Table 1). She was treated with blood transfusion and other supportive (c) 2021. The Indian Association of Laboratory Physicians.

This is an open access article published by Thieme under the terms of the Creative Commons Attribution-NonDerivative-NonCommercial-License, permitting copying and reproduction so long as the original work is given appropriate credit. Contents may not be used for commercial purposes, or adapted, remixed, transformed or built upon. (https://creativecommons.org/licenses/by-nc-nd/4.0/).

Thieme Medical and Scientific Publishers Pvt. Ltd. A-12, 2nd Floor, Sector 2, Noida-201301 UP, India 
Table 1 Showing hemoglobin level, liver functions, and plasma calcium for the two patients

\begin{tabular}{|l|l|l|l|}
\hline & Case 1 (renal cell cancer) & Case 2 (breast cancer) & Normal reference range \\
\hline $\mathrm{Hb}$ & 63 & 109 & $110-150 \mathrm{~g} / \mathrm{dL}$ \\
\hline ALT & 12 & 529 & $1-34 \mathrm{mmol} / \mathrm{L}$ \\
\hline GGT & 16 & 1,185 & $0-37 \mathrm{mmol} / \mathrm{L}$ \\
\hline ALP & 75 & 916 & $30-130 \mathrm{mmol} / \mathrm{L}$ \\
\hline Bilirubin & 9 & 122 & $3-21 \mathrm{mmol} / \mathrm{L}$ \\
\hline Plasma calcium & 2.43 & 2.18 & $2.2-2.6 \mathrm{mmol} / \mathrm{L}$ \\
\hline
\end{tabular}

Abbreviations: ALP, alkaline phosphatase; ALT, alanine aminotransferase; GGT, gamma-glutamyl transferase; Hb, hemoglobin.

measures. Subsequent endoscopy showed presence of ulcerating lesion in the ampulla of $\operatorname{Vater}(\boldsymbol{-}$ Fig. 1) Computed tomography scan (CT) showed the presence of mass in the ampulla of Vater (-Figs. 2). which was biopsied during endoscopy. Histological assessment of the biopsy specimens confirmed the presence of metastasis from renal cell cancer (-Fig. $\mathbf{3}$ ). Patient was discharged home after the endoscopic management. Unfortunately, few weeks later she was re-admitted with another episode of upper gastrointestinal bleeding and the decision was to undertake palliative care only this time. Due to her underlying comorbidities and frailty, endoscopic therapy or angioembolization was deemed unsuitable via interventional radiology. Consequently, only palliative care was instituted. She sadly passed away after a few days.

\section{Case 2}

The second patient was a 54-year-old female with known breast cancer and bone metastasis. Past medical history included Crohn's disease, which was in remission on Pentasa maintenance therapy $2 \mathrm{~g} / \mathrm{d}$. She developed jaundice few weeks before the presentation and CT scan showed biliary dilation and axial view of CT scan showed large soft tissue in the ampulla of Vater (-Figs. 4, 5) (-Table 1). Subsequent

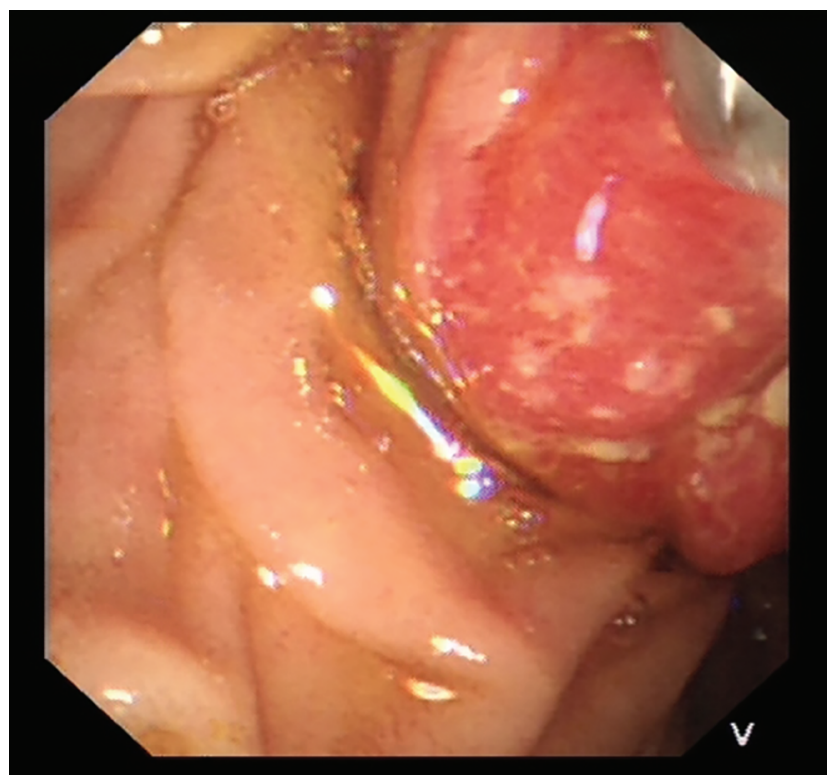

Fig. 1 Duodenal endoscopy showed large highly vascular ulcerating mass lesion in the ampulla of Vater in case of renal cell cancer metastasis (case 1).

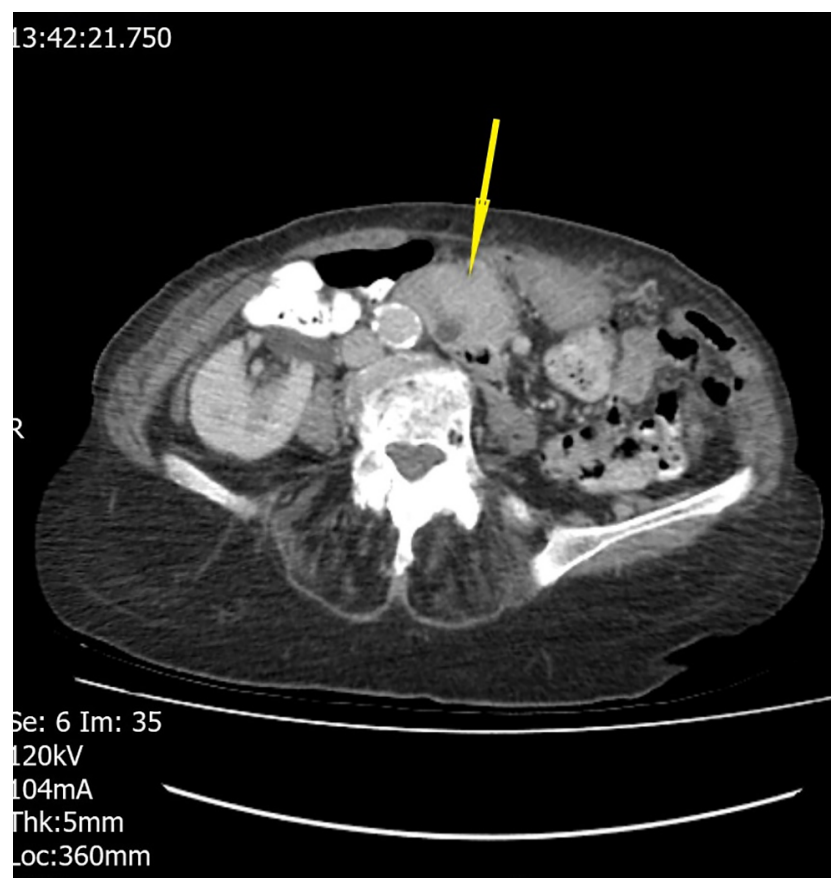

Fig. 2 Axial view of CT scan showing the presence of duodenal cancer in case of renal cell cancer metastasis (case 1).

endoscopic retrograde cholangiopancreatography (ERCP) showed large, obstructive lesion in ampulla of Vater ( - Fig. 4). The histological examination of the biopsy specimen from the lesion taken during the endoscopy confirmed the presence of metastasis of breast cancer to ampulla of Vater ( - Fig. 6 ). The bile duct could not be cannulated during ERCP and therefore she underwent PTC (percutaneous transhepatic cholangiography) and was successfully stented radiologically, causing dramatic resolution of her cholestasis. She was subsequently put on an alternative regime of chemotherapy by the oncologist for her breast cancer and is making satisfactory progress both clinically and radiologically, with significant regression of her primary disease. She is still doing well a year after diagnosis with the radiologically inserted stent in situ, and no recurrence of biliary obstruction. However, the prognosis remains guarded.

\section{Discussion}

The total number of renal cell cancer with metastasis to ampulla of Vater according to Sarocchi et al was $11 .^{2}$ In seven 


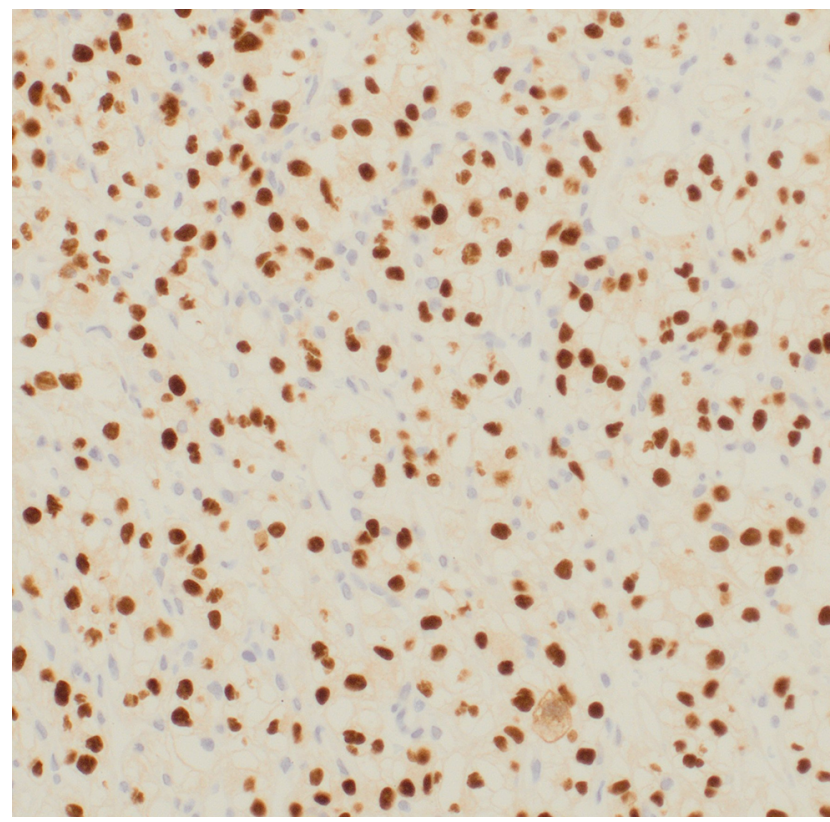

Fig. 3 The immunohistochemistry for renal cell carcinoma from the sample taken from the tumor in the ampulla of Vater (case 1). It is renal cell cancer metastasis. The cells have clear cytoplasm. All the brown dots are the positive cancer cells/nuclei. Some nuclei are not taking the brown stain and they are vessels and fibroblasts. Positive staining was found for $A E 1 / 3, \operatorname{Pax} 8, C D 10$, vimentin and EMA and these are consistent with renal cell cancer. The stains were negative for CK7, CK20, and TTF-1. EMA, epithelial membrane antigen.

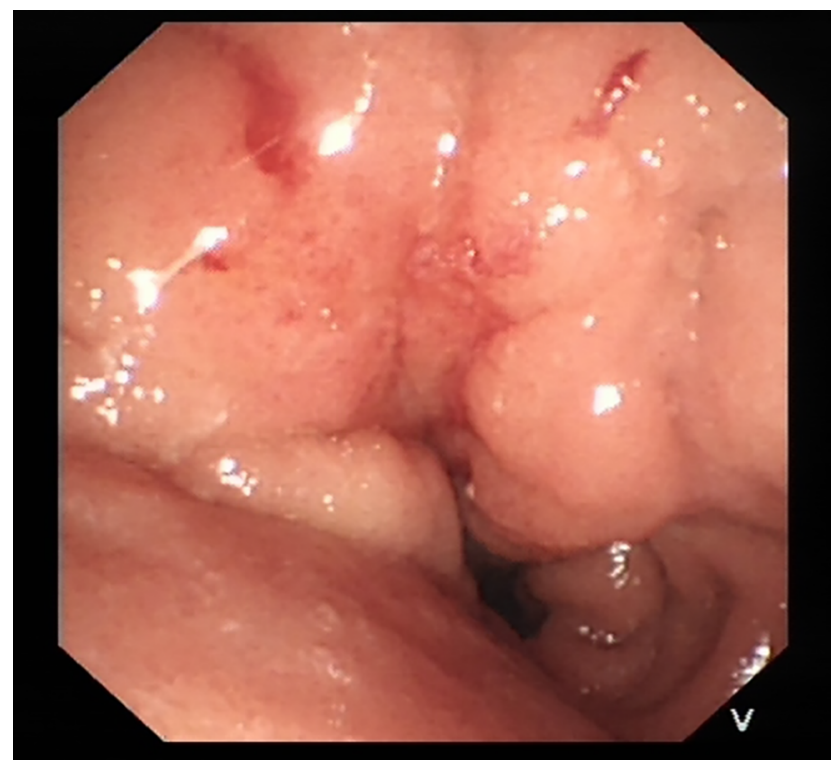

Fig. 4 Showing ERCP with bulky ampulla of Vater in patient with breast cancer (case 2). ERCP, endoscopic retrograde cholangiopancreatography.

of these patients, upper gastrointestinal bleeding was the main presentation. This is similar to the clinical presentation in the first case. The average time from diagnosis of renal cell carcinoma till metastasis to ampulla of Vater is around 10 years. $^{2}$ This is also almost similar to our case report as metastasis to ampulla of Vater occurred 8 years after the diagnosis of renal cell carcinoma. Renal cell cancer is highly

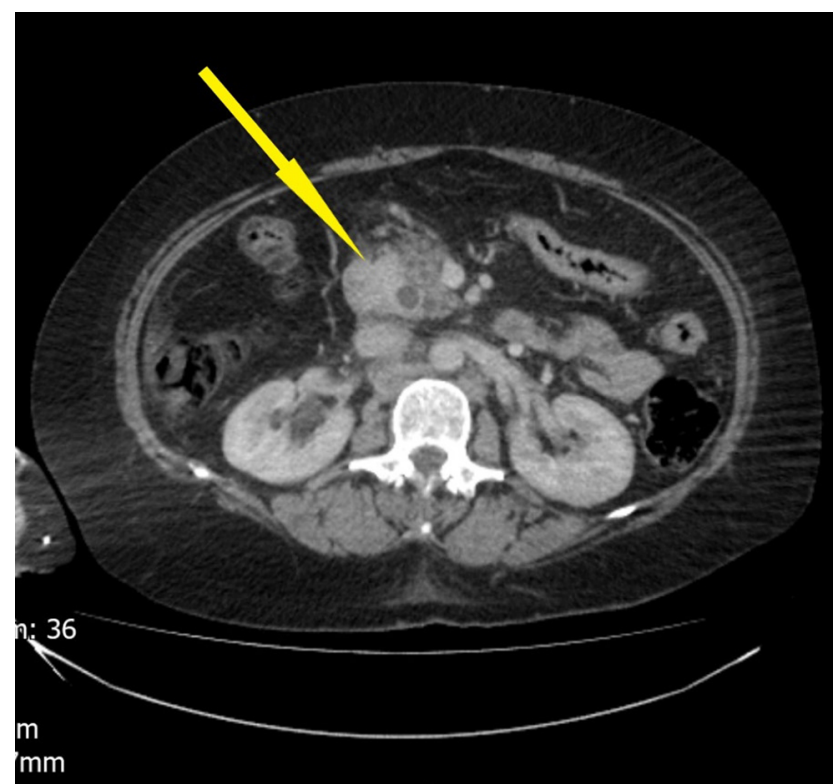

Fig. 5 CT showing large soft tissue in the ampulla of Vater in patient with breast cancer (case 2).

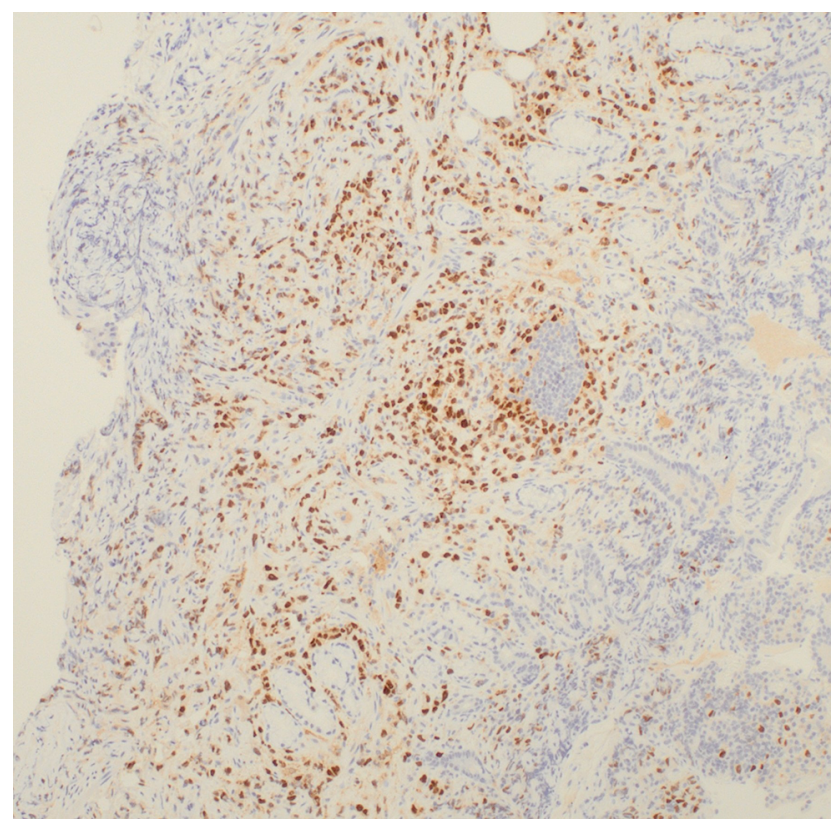

Fig. 6 The immunohistochemistry of breast cell cancer from the sample taken from the tumor in the ampulla of Vater (case 2). It is breast cancer metastasis. All the brown dots are ER positive cells. Strong positivity was found with cytokeratin and estrogen receptors and this was consistent breast cancer metastasis. Immunostaining was negative for HER-2.

vascular and can therefore present with significant gastrointestinal bleeding and/or anemia., ${ }^{5,6}$ This also can make upper gastrointestinal endoscopy difficult as taking of biopsies may need special expertise to avoid fatal bleeding. It is worth mentioning, that renal cell carcinoma can also present with obstructive jaundice. ${ }^{7}$ Since the publication of Sarocchi et al in 2017, other four case reports were published..$^{6,8-10}$ Therefore, the total case reports of renal cell carcinoma with metastasis to ampulla of Vater including our report will be 16 cases. 
Breast cancer with metastasis to ampulla of Vater can present with upper gastrointestinal bleeding, jaundice, nausea, and vomiting. ${ }^{11-14}$ The presentation in the second case was with obstructive jaundice. The average time from diagnosis of breast cancer till metastasis to ampulla of Vater was around 3 years. In the second case, the metastasis to ampulla of Vater was found 3 years from the diagnosis of breast cancer.

BRCA1 and BRCA2 mutations are established markers for hereditary breast and ovarian cancer, and it can also be associated with increased risk of other rare cancers like cancer of pancreas. Importantly, Pinto et al identified high frequency of germline BRCA2 mutations in metastatic ampullary cancers as well. ${ }^{15}$ This may raise the potential in future of using molecular biology techniques in combination with imaging alone to diagnose these cases, without resorting to performing hazardous endoscopies, or where taking of biopsy can result in fatal complications or is inappropriate. The possible learning points from these two cases are: (1) Metastasis to ampulla of Vater is very rare. More common neoplastic involvement of papilla is extension from pancreatic or biliary tumors; (2) Common cancers with metastasis to ampulla of Vater are malignant melanoma, renal cell cancer, and breast cancer; (3) Common presentations include obstructive jaundice or upper gastrointestinal bleeding. Taking biopsies from renal cell cancer can be quite hazardous as it is highly vascular; (4) Germline BRCA2 mutations can be found in metastatic ampullary cancers from breast cancer as well.

\section{Authors' Contribution}

J.A., A.K., M.H.A., and R.M. wrote the manuscript. All authors edited the manuscript and approved the final version. M.H.A. is the article guarantor.

\section{Funding \\ None.}

\section{Informed Consent}

Informed and written consent was obtained for both cases reported in this manuscript.

\section{Conflict of Interest}

None declared.

\section{References}

1 Allescher HD. Papilla of Vater: structure and function. Endoscopy 1989;21(suppl 1) :324-329

2 Sarocchi F, Gilg MM, Schreiber F, Langner C. Secondary tumours of the ampulla of Vater: case report and review of the literature. Mol Clin Oncol 2018;8(2):274-280

3 Pea A, Riva G, Bernasconi R, et al. Ampulla of Vater carcinoma: molecular landscape and clinical implications. World J Gastrointest Oncol 2018;10(11):370-380

4 Perysinakis I, Margaris I, Kouraklis G. Ampullary cancer-a separate clinical entity? Histopathology 2014;64(6):759-768

5 Robertson GS, Gertler SL. Late presentation of metastatic renal cell carcinoma as a bleeding ampullary mass. Gastrointest Endosc 1990;36(3):304-306

6 Nakamura T, Oe N, Matsumori T. A hypervascular mass at the papilla of Vater. Gastroenterology 2019;156(6):e7-e9

7 Bolkier M, Ginesin Y, Moskovitz B, Munichor M, Levin DR. Obstructive jaundice caused by metastatic renal cell carcinoma. Eur Urol 1991;19(1):87-88

8 Ignatavicius P, Lizdenis P, Pranys D, Gulbinas A, Pundzius J, Barauskas G. Long-term survival of patient with ampulla of Vater metastasis of renal cell carcinoma. Prague Med Rep 2018;119(4):165-169

9 Kling SM, Tannouri S, Jiang W, Yeo CJ. Pancreatic mass in a patient with a history of resected renal cell carcinoma and resected adenocarcinoma of the ampulla of Vater: a case report. J Pancreat Cancer 2018;4(1):41-44

10 Cheong D, Rho SY, Kim JH, Kang CM, Lee WJ. Laparoscopic pancreaticoduodenectomy for renal cell carcinoma metastasized to ampulla of Vater: a case report and literature review. Ann Hepatobiliary Pancreat Surg 2018;22(1):83-89

11 Rego RF, Atiq M, Velchala N, et al. Ampullary metastasis from breast cancer: an unusual finding. Endoscopy 2009;41(suppl 2) :E278-E279

12 Titus AS, Baron TH, Listinsky CM, Vickers SM. Solitary breast metastasis to the ampulla and distal common bile duct. Am Surg 1997;63(6):512-515

13 Bastos T, Souza TF, Otoch JP, Grecco E, Àvila F, Artifon EL. Metastasis of breast cancer to major duodenal papilla. Rev Gastroenterol Peru 2014;34(2):149-150

14 Giestas S, Lopes S, Souto P, et al. Ampullary metastasis from breast cancer: a rare cause of obstructive jaundice. GE Port J Gastroenterol 2016;23(6):300-303

15 Pinto P, Peixoto A, Santos C, et al. Analysis of founder mutations in rare tumors associated with hereditary breast/ovarian cancer reveals a novel association of BRCA2 mutations with ampulla of Vater carcinomas. PLoS One 2016;11(8):e0161438 